Original paper

\title{
Taurine mitigates cirrhosis-associated heart injury through mitochondrial-dependent and antioxidative mechanisms
}

\author{
Khadijeh Mousavi 1,2, Hossein Niknahad ${ }^{1,2}$, Amin Ghalamfarsa ${ }^{1,2}$, Hamidreza Mohammadi1,2, Negar Azarpira3, \\ Mohammad Mehdi Ommati ${ }^{4}$, Reza Heidari ${ }^{2}$ \\ 'Department of Pharmacology and Toxicology, School of Pharmacy, Shiraz University of Medical Sciences, Shiraz, Iran \\ 2Pharmaceutical Sciences Research Center, Shiraz University of Medical Sciences, Shiraz, Iran \\ ${ }^{3}$ Transplant Research Center, Shiraz University of Medical Sciences, Shiraz, Iran \\ ${ }^{4}$ College of Life Sciences, Shanxi Agricultural University, Taigu, Shanxi, P.R. China
}

\begin{abstract}
Cirrhosis-induced heart injury and cardiomyopathy is a serious consequence of this disease. It has been shown that bile duct ligated (BDL) animals could serve as an appropriate experimental model to investigate heart tissue injury in cirrhosis. The accumulation of cytotoxic chemicals (e.g., bile acids) could also adversely affect the heart tissue. Oxidative stress and mitochondrial impairment are the most prominent mechanisms of bile acid cytotoxicity. Taurine (Tau) is the most abundant non-protein amino acid in the human body. The cardioprotective effects of this amino acid have repeatedly been investigated. In the current study, it was examined whether mitochondrial dysfunction and oxidative stress are involved in the pathogenesis of cirrhosis-induced heart injury. Rats underwent BDL surgery. BDL animals received Tau (50, 100, and $500 \mathrm{mg} / \mathrm{kg}$, i.p.) for 42 consecutive days. A significant increase in oxidative stress biomarkers was detected in the heart tissue of BDL animals. Moreover, it was found that heart tissue mitochondrial indices of functionality were deteriorated in the BDL group. Tau treatment significantly decreased oxidative stress and improved mitochondrial function in the heart tissue of cirrhotic animals. These data provide clues for the involvement of mitochondrial impairment and oxidative stress in the pathogenesis of heart injury in BDL rats. On the other hand, Tau supplementation could serve as an effective ancillary treatment against BDL-associated heart injury. Mitochondrial regulating and antioxidative properties of Tau might play a fundamental role in its mechanism of protective effects in the heart tissue of BDL animals.
\end{abstract}

Key words: amino acid, bioenergetics, cardiomyopathy, cirrhosis, heart failure, mitochondrial impairment.

Address for correspondence:

Dr. Reza Heidari, Pharmaceutical Sciences Research Center, Shiraz University of Medical Sciences, Shiraz, P.O. Box 1583; 71345, Roknabad, Karafarin St., Shiraz, Fars, Iran, phone: +98-7132424126-282, e-mail: rezaheidari@hotmail.com and Mohammad Mehdi Ommati, College of Life Sciences, Shanxi Agricultural University, Taigu, Shanxi, P.R. China, phone: +86-15703449654, fax: +86-354-6288181, e-mail: Mehdi_Ommati@sums.ac.ir

\section{Introduction}

Heart injury and hemodynamic abnormalities are common complications in cirrhotic patients [1-5]. Cardiac contraction abnormalities and decreased cardiac output, besides arrhythmia and heart failure, could occur in cirrhosis [1-5]. Liver transplantation is the only accepted standard intervention for the man- agement of cirrhosis-associated cardiac impairment. Unfortunately, there is a scarcity of cellular and molecular studies on the mechanisms involved in cardiac impairment induced by cirrhosis. On the other hand, no particular pharmacological intervention has been developed to prevent heart tissue injury in cirrhotic patients. 
Taurine (Tau) is the most abundant non-protein amino acid in the human body. Several physiological as well as pharmacological properties have been attributed to Tau [6-8]. It has been found that Tau treatment effectively blunts xenobiotic-induced organ injury [9-15]. Moreover, it has been well documented that several diseases could benefit from exogenous Tau supplementation [6, 16-19].

The beneficial effects of Tau have been demonstrated in a wide range of cardiovascular diseases [20-22]. The positive effects of Tau on high plasma cholesterol, coronary artery diseases, congestive heart failure, and myocardial function have been documented [20-22]. The antioxidant role of Tau has been mentioned as a fundamental mechanism involved in the cardioprotective effects of this amino acid [23-25]. It has been found that Tau protects heart tissue against toxic insults by alleviation of oxidative stress and its associated events [10, 26-31]. Interestingly, recent studies mentioned that the antioxidant effect of Tau is indirectly mediated by the effects of this amino acid on cellular mitochondria [16, 32-37].

It has been found that Tau significantly improved mitochondrial function and energy metabolism [16, 38, 39]. Tau could also significantly decrease mitochondria-derived reactive oxygen species (ROS) [40-43]. The release of cell death mediators from mitochondria and suppression of mitochondria-mediated cell death are also evident upon Tau administration [40, 44, 45].

The current study was designed to evaluate the role of mitochondrial dysfunction and oxidative stress in the heart tissue of cirrhotic animals. Additionally, the impact of Tau supplementation on cardiac dysfunction in cirrhosis was monitored.

\section{Material and methods}

\section{Chemicals}

2,4,6-tripyridyl-s-triazine(TPTZ),3-[4,5dimethylthiazol-2-yl]-2,5-diphenyltetrazolium bromide (MTT), 3-(N-morpholino) propane sulfonic acid (MOPS), Coomassie brilliant blue, 2',7'-dichlorofluorescein (DCFH), 6-hydroxy-2,5,7,8-tetramethylchroman-carboxylic acid (Trolox), dithiothreitol (DTT), fatty acid-free bovine serum albumin (BSA) fraction $\mathrm{V}$, ferric chloride hexahydrate $\left(\mathrm{FeCl}_{3} \cdot 6 \mathrm{H}_{2} \mathrm{O}\right)$, D-mannitol, reduced glutathione (GSH), malondialdehyde (MDA), sodium succinate, rhodamine 123 (Rh 123), oxidized glutathione (GSSG), thiobarbituric acid (TBA), taurine, sucrose, and trichloroacetic acid (TCA) were purchased from Sigma (Sigma-Aldrich, St. Louis, MO). Kits for evaluating serum biochemistry were obtained from Pars Azmun (Tehran, Iran). Dimethyl sulfoxide (DMSO), 2-amino-2-hydroxymethyl-propane-1, 4-(2-hydroxyethyl)-1-piperazineethanesulfonic acid (HEPES), dinitrofluorobenzene (DNFB), 3-diol-hydrochloride (Tris- $\mathrm{HCl}$ ), glacial acetic acid, ethylenediaminetetraacetic acid (EDTA), n-butanol, iodoacetic acid, and meta-phosphoric acid were obtained from Merck (Darmstadt, Germany).

\section{Animals}

Male Sprague-Dawley rats (200-250 g weight) were obtained from the Laboratory Animal Breeding Center, Shiraz University of Medical Sciences, Shiraz, Iran. Animals were kept in plastic cages on wood-chip bedding. The ambient temperature was $23 \pm 1^{\circ} \mathrm{C}$, with $\approx 40 \%$ relative humidity. Animals were allowed to access tap water and a rodent's pellet chow diet (Behparvar Co., Tehran, Iran). All procedures involving animal use were according to the guidelines for care and use of laboratory animals, which were approved by an institutional ethics committee in Shiraz University of Medical Sciences, Shiraz, Iran (\#95-01-36-13830).

\section{Experimental setup and animal surgery}

Rats underwent bile duct ligation (BDL) surgery. For this purpose, animals were anesthetized $(10 \mathrm{mg} / \mathrm{kg}$ of xylazine and $70 \mathrm{mg} / \mathrm{kg}$ of ketamine, i.p.), a midline incision was made along the linea alba, and the common bile duct was localized, and doubly ligated (3/0 silk suture). The sham operation consisted of laparotomy and bile duct recognition and manipulation without ligation $[46,47]$. Animals were randomly allotted to sham-operated, BDL, and BDL + taurine $(50,100$, and $500 \mathrm{mg} / \mathrm{kg} / \mathrm{day}$ ). Tau was administered by intraperitoneal injection for 42 consecutive days.

\section{Serum and urine biochemistry}

Rats were anesthetized (thiopental, $50 \mathrm{mg} / \mathrm{kg}$, i.p.), and their blood, liver, and heart samples were collected. Blood was collected from the abdominal vena cava, transferred to standard tubes (Improvacuter; gel and clot activator-coated tubes; Guangzhou, China) and centrifuged ( $3000 \mathrm{~g}, 10 \mathrm{~min}, 4^{\circ} \mathrm{C}$ ) to prepare serum. A Mindray BS-200 autoanalyzer (Mindray chemistry analyzers, Guangzhou, China) and standard kits (Pars Azmun, Tehran, Iran) were used to assess serum biochemistry including alanine aminotransferase (ALT), gamma-glutamyl transpeptidase $(\gamma-\mathrm{GT})$, creatine kinase-MB (CK-MB), aspartate aminotransferase (AST), and alkaline phosphatase (ALP). 


\section{Tissue histopathology}

For histopathological assessments, samples of heart and liver tissue were fixed in buffered formalin solution $(0.64 \%$ sodium phosphate dibasic, $0.4 \%$ sodium phosphate monobasic, and 10\% formaldehyde in double distilled water; $\mathrm{pH}=7.4$ ). Finally, paraffin-embedded sections $(5 \mu \mathrm{m})$ of tissues were stained with hematoxylin and eosin (H\&E). Masson trichrome staining was applied for fibrotic alterations. Tissue slides were blindly analyzed using a light microscope (Olympus CX21, Japan).

\section{Heart tissue reactive oxygen species (ROS) formation}

Heart tissue samples $(200 \mathrm{mg})$ were homogenized in $5 \mathrm{ml}$ of Tris- $\mathrm{HCl}$ buffer $\left(40 \mathrm{mM}, \mathrm{pH}=7.4,4^{\circ} \mathrm{C}\right)$. Afterward, $100 \mu \mathrm{l}$ of the tissue homogenate was mixed with $1 \mathrm{ml}$ of Tris- $\mathrm{HCl}$ buffer $(40 \mathrm{mM}, \mathrm{pH}=7.4)$ and $10 \mu \mathrm{l}$ of 2',7'-dichlorofluorescein diacetate (final concentration $10 \mu \mathrm{M})$ [48-50]. The mixture was incubated in the dark $\left(15 \mathrm{~min}, 37^{\circ} \mathrm{C}\right)$. Finally, the fluorescence intensity was measured using a FLUOstar Omega multifunctional microplate reader $\left(\lambda_{\text {excitation }}=485 \mathrm{~nm}\right.$ and $\left.\lambda_{\text {emission }}=525 \mathrm{~nm}\right)[51,52]$.

\section{Tissue lipid peroxidation}

Thiobarbituric acid reactive substances (TBARS) were measured to assess the amount of lipid peroxidation in the heart tissue of BDL rats [47]. Briefly, 1 $\mathrm{ml}$ of heart tissue homogenate $(10 \% \mathrm{w} / \mathrm{v}$ in Tris- $\mathrm{HCl}$ buffer, $40 \mathrm{mM}, \mathrm{pH}=7.4$ ) was added to $3 \mathrm{ml}$ of TBARS assay reaction mixture $(1 \mathrm{ml}$ of thiobarbituric acid $0.375 \%$, w/v, $2 \mathrm{ml}$ of trichloroacetic acid 15\%; w/v, and $1 \mathrm{ml}$ of hydrochloric acid $12 \mathrm{~N}, \mathrm{pH}=2)$. Samples were mixed well and heated in a water bath $\left(100^{\circ} \mathrm{C}, 45 \mathrm{~min}\right)$ [48, 53-55]. Finally, n-butanol (2 ml) was added and vigorously mixed. Samples were centrifuged (3000 g, $10 \mathrm{~min}$ ), and the absorbance of the developed color in the n-butanol (upper phase) was measured $(\lambda=532 \mathrm{~nm}$, EPOCH plate reader, BioTek instruments, Highland Park, USA) [56].

\section{Ferric reducing antioxidant power (FRAP) of the heart tissue}

The formation of $\mathrm{Fe}^{2+}$-tripyridyltriazine complex (blue colored) from the colorless oxidized $\mathrm{Fe}^{3+}$ was measured by FRAP assay [57]. Briefly, $100 \mu \mathrm{l}$ of tissue homogenate $(10 \% \mathrm{w} / \mathrm{v}$ in Tris- $\mathrm{HCl}$ buffer, $40 \mathrm{mM}$, $\mathrm{pH}=7.4$ ) was added to $1 \mathrm{ml}$ of the freshly prepared
FRAP reagent (10 volumes of acetate buffer $300 \mathrm{mmol} / \mathrm{l}$, $\mathrm{pH}=3.6,1$ volume of TPTZ $10 \mathrm{mmol} / 1$ in $40 \mathrm{mmol} / \mathrm{l}$ hydrochloric acid $6 \mathrm{~N}$; and 1 volume of ferric chloride $20 \mathrm{mmol} / \mathrm{l}$ in deionized water) [58]. Samples were incubated at $37^{\circ} \mathrm{C}$ for 5 minutes (protected from light). The absorbance of developed color was measured at $\lambda=595 \mathrm{~nm}$ (EPOCH plate reader, BioTek instruments, Highland Park, USA) [59].

\section{Tissue protein carbonylation}

The oxidative damage of proteins was assessed by the determination of carbonyl groups based on the reaction with dinitrophenylhydrazine (DNPH) $[60,61]$. Briefly, $100 \mu \mathrm{l}$ of TCA $\left(20 \% \mathrm{w} / \mathrm{v}, 4^{\circ} \mathrm{C}\right)$ was added to $1 \mathrm{ml}$ of the heart tissue homogenate and centrifuged (700 g, $15 \mathrm{~min}$ ). Then, $500 \mu \mathrm{l}$ of $10 \mathrm{mM} \mathrm{DNPH}$ (dissolved in $2 \mathrm{~N} \mathrm{HCl}$ ) was added to the supernatant. Samples were then incubated for 1 hour in the dark at room temperature with vortexing every 10 minutes. Afterward, $100 \mu \mathrm{l}$ of TCA $(20 \% \mathrm{w} / \mathrm{v})$ was added, and the tubes were centrifuged $(12,000 \mathrm{~g}$ for $5 \mathrm{~min})$. The supernatant was discarded, and the pellet was washed three times with $1 \mathrm{ml}$ of ethanol : ethyl acetate $(1: 1 \mathrm{v} / \mathrm{v})$. The precipitate was re-dissolved in $600 \mu$ of guanidine solution (6 M, with $20 \mathrm{mM}$ potassium phosphate, adjusted to $\mathrm{pH}=2.3$ with trifluoroacetic acid, for $15 \mathrm{~min}$, $37^{\circ} \mathrm{C}$ ) and the absorbance at $\lambda=370 \mathrm{~nm}$ was measured (EPOCH plate reader, BioTek instruments, Highland Park, USA) [60].

\section{Heart tissue mitochondria isolation}

Rat heart was excised, washed, and minced in an ice-cold $\left(4^{\circ} \mathrm{C}\right)$ isolation buffer medium $(70 \mathrm{mM}$ mannitol, 2 mM HEPES, $220 \mathrm{mM}$ sucrose, $0.5 \mathrm{mM}$ EGTA and $0.1 \%$ BSA dissolved in ion-free double distilled water, $\mathrm{pH}=7.4)$ containing trypsin $(0.1 \% \mathrm{w} / \mathrm{v})[62,63]$. Samples were incubated on ice for 15 minutes and centrifuged $\left(15,000 \mathrm{~g}, 10 \mathrm{~min}, 4^{\circ} \mathrm{C}\right)$. The supernatant was discarded, and the pellet (heart tissue) was transported into the new isolation buffer $(10 \mathrm{ml}$ buffer $/ 1 \mathrm{~g}$ of the heart tissue, $\left.4^{\circ} \mathrm{C}\right)$. Tissue samples were homogenized, and mitochondria were isolated by differential centrifugation of the heart homogenate $[62,63]$. First, unbroken cells and nuclei were pelleted (1000 g for $20 \mathrm{~min}$ at $\left.4^{\circ} \mathrm{C}\right)$. Second, the supernatant was centrifuged $\left(10,000 \mathrm{~g}\right.$ for $20 \mathrm{~min}$ at $\left.4^{\circ} \mathrm{C}\right)$ to pellet the mitochondrial fraction. This step was repeated at least three times using a fresh isolation buffer medium to increase the mitochondrial yield $[47,63,64]$. The mitochondrial fraction pellets (dark brown) were suspended in the incubation buffer containing $225 \mathrm{mM}$ sucrose, 
$75 \mathrm{mM}$ mannitol, $0.5 \mathrm{mM}$ EGTA, and $2 \mathrm{mM}$ HEPES, $\mathrm{pH}=7.4$, except for the mitochondrial preparations mitochondrial depolarization, and mitochondrial permeabilization, which were resuspended in mitochondrial depolarization assay buffer $(225 \mathrm{mM}$ sucrose, $10 \mathrm{mM}$ $\mathrm{KCl}, 2 \mathrm{mM} \mathrm{MgCl}, 5 \mathrm{mM} \mathrm{KH} \mathrm{PO}_{4}, 75 \mathrm{mM}$ mannitol, $50 \mu \mathrm{M}$ EGTA, and $10 \mathrm{mM}$ HEPES, $\mathrm{pH}=7.2$ ) and swelling buffer $(250 \mathrm{mM}$ sucrose, $2 \mathrm{mM}$ HEPES, $0.5 \mathrm{mM}$ $\mathrm{KH}_{2} \mathrm{PO}_{4}, \mathrm{pH}=7.2$ ) [47]. Samples' protein concentrations were assessed by the Bradford method to standardize the obtained data [65].

\section{Mitochondrial dehydrogenases activity}

Based on a previously described protocol, the reduction of 3-(4,5-dimethylthiazol-2-yl)-2, 5-diphenyltetrazolium bromide by mitochondrial dehydrogenases was determined [66-68]. Briefly, a mitochondrial suspension $(1 \mathrm{mg}$ protein $/ \mathrm{ml})$ was incubated with $40 \mu \mathrm{l}$ of MTT $\left(0.4 \% \mathrm{w} / \mathrm{v}, 37^{\circ} \mathrm{C}, 30 \mathrm{~min}\right.$, in the dark). Then, samples were centrifuged $(16,000 \mathrm{~g}, 10 \mathrm{~min})$ and the pellet (product of purple formazan crystals) was dissolved in $1 \mathrm{ml}$ of dimethyl sulfoxide. Finally, the optical density (OD) of samples was measured (EPOCH plate reader, $\lambda=570 \mathrm{~nm}$, Bio-Tek Instruments, Highland Park, USA) $[48,69]$.

\section{Mitochondrial depolarization}

The mitochondrial capacity to capture the cationic fluorescent dye, rhodamine 123 , was used to estimate mitochondrial depolarization [47, 62, 70-74]. Rhodamine 123 accumulates in the mitochondrial matrix by facilitated diffusion. When the mitochondrion is damaged and depolarized, there is no facilitated diffusion. Therefore, the amount of rhodamine 123 in the supernatant is increased [47, 62, 70-73]. In the current study, the mitochondrial fractions $(1 \mathrm{mg}$ protein $/ \mathrm{ml})$ were incubated with rhodamine 123 (final concentration of $10 \mu \mathrm{M}, 15 \mathrm{~min}$, in the dark, with continuous shaking) [48, 75]. Afterward, samples were centrifuged $\left(16,000 \mathrm{~g}, 1 \mathrm{~min}, 4^{\circ} \mathrm{C}\right)$, and the fluorescence intensity of the supernatant was monitored (FLUOstar Omega multifunctional microplate reader, BMG Labtech Inc., Germany, $\lambda_{\text {excitation }}=485 \mathrm{~nm}$ and $\lambda$ emission $=525 \mathrm{~nm})[62,76]$.

\section{Mitochondrial permeabilization}

Based on a previously reported protocol, the changes in the light scattering of isolated mitochondria samples at $\lambda=540 \mathrm{~nm}$ was used as an estimate of the mitochondrial swelling and permeabilization $[47,62$, $76]$. Briefly, isolated heart mitochondria $(0.5 \mathrm{mg}$ pro- tein $/ \mathrm{ml})$ were suspended in swelling buffer $(250 \mathrm{mM}$ sucrose, $2 \mathrm{mM}$ HEPES, $0.5 \mathrm{mM} \mathrm{KH}_{2} \mathrm{PO}_{4}, \mathrm{pH}=7.2$ ) [77]. Then, $100 \mu \mathrm{l}$ of mitochondrial suspension was transferred to a 96-well plate, and the mitochondrial permeability transition was initiated by adding calcium chloride (final concentration $50 \mu \mathrm{M}$ ). The optical density at $\lambda=540 \mathrm{~nm}$ was monitored for 30 minutes (EPOCH plate reader, Bio-Tek Instruments, Highland Park, USA) [76, 78]. A decrease in the absorbance is associated with an increase in mitochondrial volume and organelle swelling $[62,76]$.

\section{HPLC analysis of heart tissue and isolated mitochondria glutathione content}

The reduced (GSH) and oxidized (GSSG) glutathione levels in the heart tissue and isolated mitochondria samples were assessed by the HPLC analysis of deproteinized samples (TCA 50\% w/v) after derivatization with iodoacetic acid and fluoro-2,4-dinitrobenzene, using a $25 \mathrm{~cm} \mathrm{NH}_{2}$ column (Bischoff chromatography, Leonberg, Germany), and the flow rate $1 \mathrm{ml} / \mathrm{min}$ [79]. The mobile phases consisted of buffer A (water : methanol, $1: 4 \mathrm{v} / \mathrm{v}$ ) and buffer B (acetate buffer : methanol, $1: 4 \mathrm{v} / \mathrm{v}$ ) and a gradient method with a steady increase of buffer B to $95 \%$ in 20 minutes [77, 79, 80]. Nanomole levels of GSH and GSSG can be measured by this method [79]. GSSG and GSH were used as external standards. Heart tissue samples $(200 \mathrm{mg})$ were homogenized in Tris- $\mathrm{HCl}$ buffer $\left(250 \mathrm{mM}, \mathrm{pH}=7.4,4^{\circ} \mathrm{C}\right)$, and $500 \mu \mathrm{l}$ of TCA $\left(50 \% \mathrm{w} / \mathrm{v}, 4^{\circ} \mathrm{C}\right)$ was added. Mitochondria samples (500 $\mu \mathrm{l}, 1 \mathrm{mg}$ protein $/ \mathrm{ml}$ ) were also treated with $50 \mu \mathrm{l}$ of TCA $\left(50 \% \mathrm{w} / \mathrm{v}, 4^{\circ} \mathrm{C}\right)$ and incubated for 15 minutes on ice. Afterward, samples were mixed well and centrifuged $\left(15,000 \mathrm{~g}, 15 \mathrm{~min}, 4^{\circ} \mathrm{C}\right)$. Then, $1 \mathrm{ml}$ of the supernatant was collected, and $400 \mu \mathrm{l}$ of the $\mathrm{NaOH}: \mathrm{NaHCO}_{3}$ ( $2 \mathrm{M}: 2 \mathrm{M}$ ) was added until the gas production subsided. Afterward, $100 \mu \mathrm{l}$ of iodoacetic acid $(1.5 \% \mathrm{w} / \mathrm{v}$ in water) was added, and samples were incubated for one hour $\left(4^{\circ} \mathrm{C}\right.$, in the dark). After the incubation period, $500 \mu \mathrm{l}$ of 2,4-dinitrofluorobenzene (DNFB, $1.5 \% \mathrm{w} / \mathrm{v}$ in absolute ethanol) was added and incubated in the dark $\left(25^{\circ} \mathrm{C}\right.$, at least for 48 hours). Finally, $25 \mu \mathrm{l}$ of samples were injected into the described HPLC system. The UV detector was fixed at $\lambda=252 \mathrm{~nm}[79,81]$.

\section{Mitochondrial ATP content}

A luciferase-luciferin-based kit (Enliten, Promega, Madison, WI) was used to measure mitochondrial ATP content $[82,83]$. Samples and buffer solutions were prepared based on the kit instructions. Briefly, $500 \mu \mathrm{l}$ of mitochondrial samples $(1 \mathrm{mg}$ protein $/ \mathrm{ml}$ ) were treated 
with $100 \mu \mathrm{l}$ of ice-cooled TCA solution $(0.5 \% \mathrm{w} / \mathrm{v}$ in double-distilled water) and centrifuged $(15,000 \mathrm{~g}, 15 \mathrm{~min}$, $4^{\circ} \mathrm{C}$ ). Afterward, $100 \mu \mathrm{l}$ of ATP kit content was added to $100 \mu \mathrm{l}$ of the supernatant (in the dark), and the luminescence intensity of samples was measured $(\lambda=560 \mathrm{~nm}$ using a FLUOstar Omega multifunctional microplate reader, BMG Labtech Inc., Germany) [83].

\section{Lipid peroxidation in heart mitochondria}

Thiobarbituric acid reactive substances (TBARS) were measured as an index of lipid peroxidation in isolated heart mitochondria according to a previously reported procedure $[62,76]$. Isolated mitochondria were washed to remove sucrose (as a TBARS test interfering agent) using an ice-cold MOPS-KCl buffer (100 mM $\mathrm{KCl}, 50 \mathrm{mM} \mathrm{MOPS}, \mathrm{pH}=7.4,4^{\circ} \mathrm{C}$ ), and re-suspended in fresh MOPS- $\mathrm{KCl}$ buffer [62]. Then, the mitochondrial suspension was mixed with twice its volume of a mixture containing trichloroacetic acid (TCA $15 \% \mathrm{w} / \mathrm{v}$ ), thiobarbituric acid (TBA $0.375 \% \mathrm{w} / \mathrm{v}$ ), $100 \mu \mathrm{l}$ of $0.24 \mathrm{~N}$ $\mathrm{HCl}$, plus $0.5 \mathrm{mM}$ Trolox. Samples were heated for
15 minutes in a water bath $\left(100^{\circ} \mathrm{C}\right)[62,84]$. After centrifugation $(15,000 \mathrm{~g}, 5 \mathrm{~min})$, the absorbance of the supernatant was measured $(\lambda=532 \mathrm{~nm}, \mathrm{EPOCH}$ plate reader, BioTek instruments, Highland Park, USA).

\section{Statistical analysis}

Data are represented as the mean $\pm \mathrm{SD}$. Data comparison was performed by the one-way analysis of variance (ANOVA) with Tukey's multiple comparison test as the post hoc test. $P<0.05$ was considered to indicate a statistically significant difference between groups.

\section{Results}

Significant changes in serum biochemical parameters were evident in the BDL group (Fig. 1). Extreme elevation in serum ALP and $\gamma$-GT confirmed bile duct injury in the BDL rats. Moreover, serum bilirubin and bile acid levels were significantly higher in the BDL rats. On the other hand, it was found that Tau supplemen-
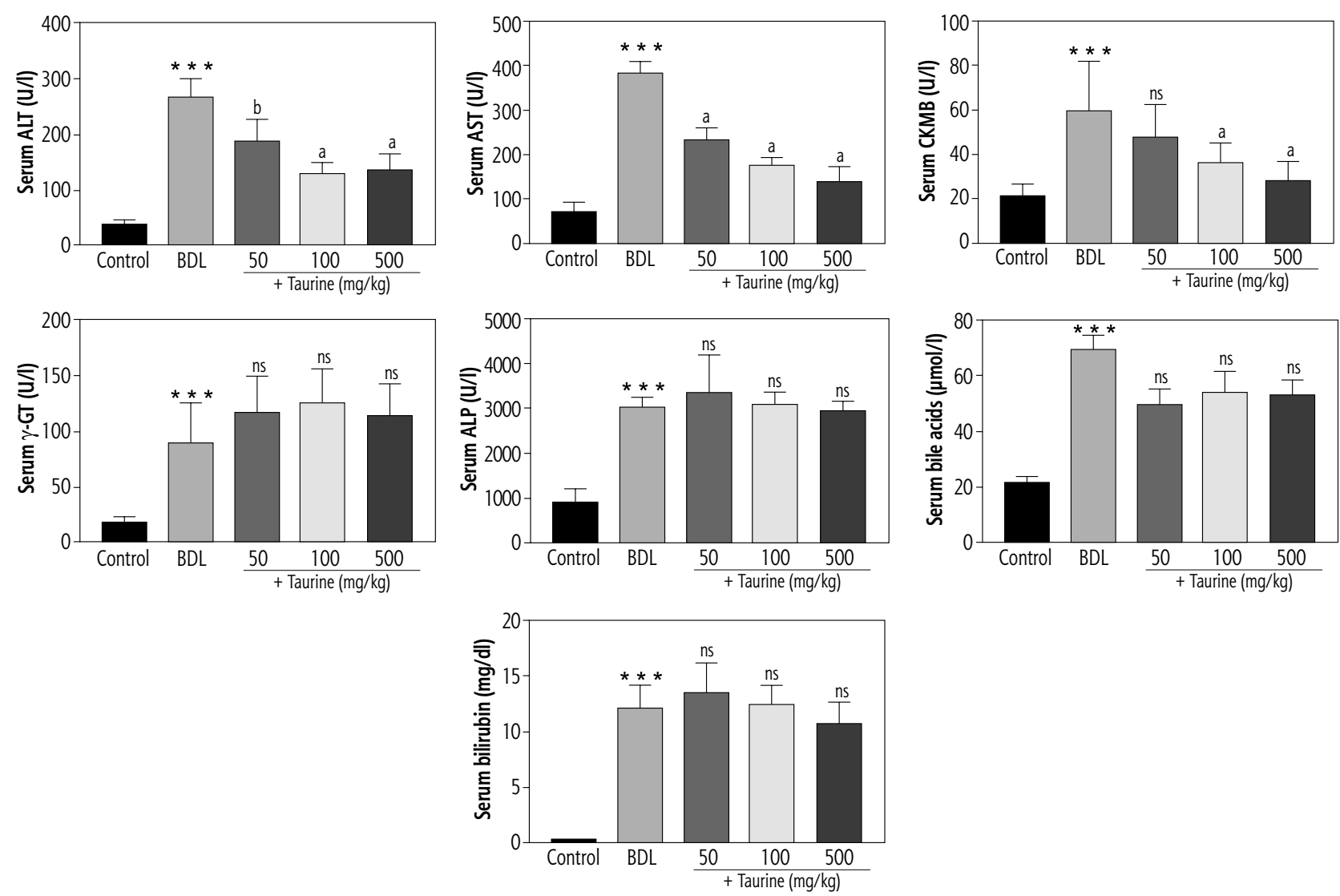

*** Significantly different as compared with the control group $(p<0.001)$

$a, b$ Significantly different as compared with the BDL group ( $p<0.001$ and $p<0.05$ respectively)

ns - not significant as compared with the BDL group

Fig. 1. Serum biomarkers of organ injury in bile duct ligated (BDL) rats. Data are given as mean $\pm S D(n=8)$ 

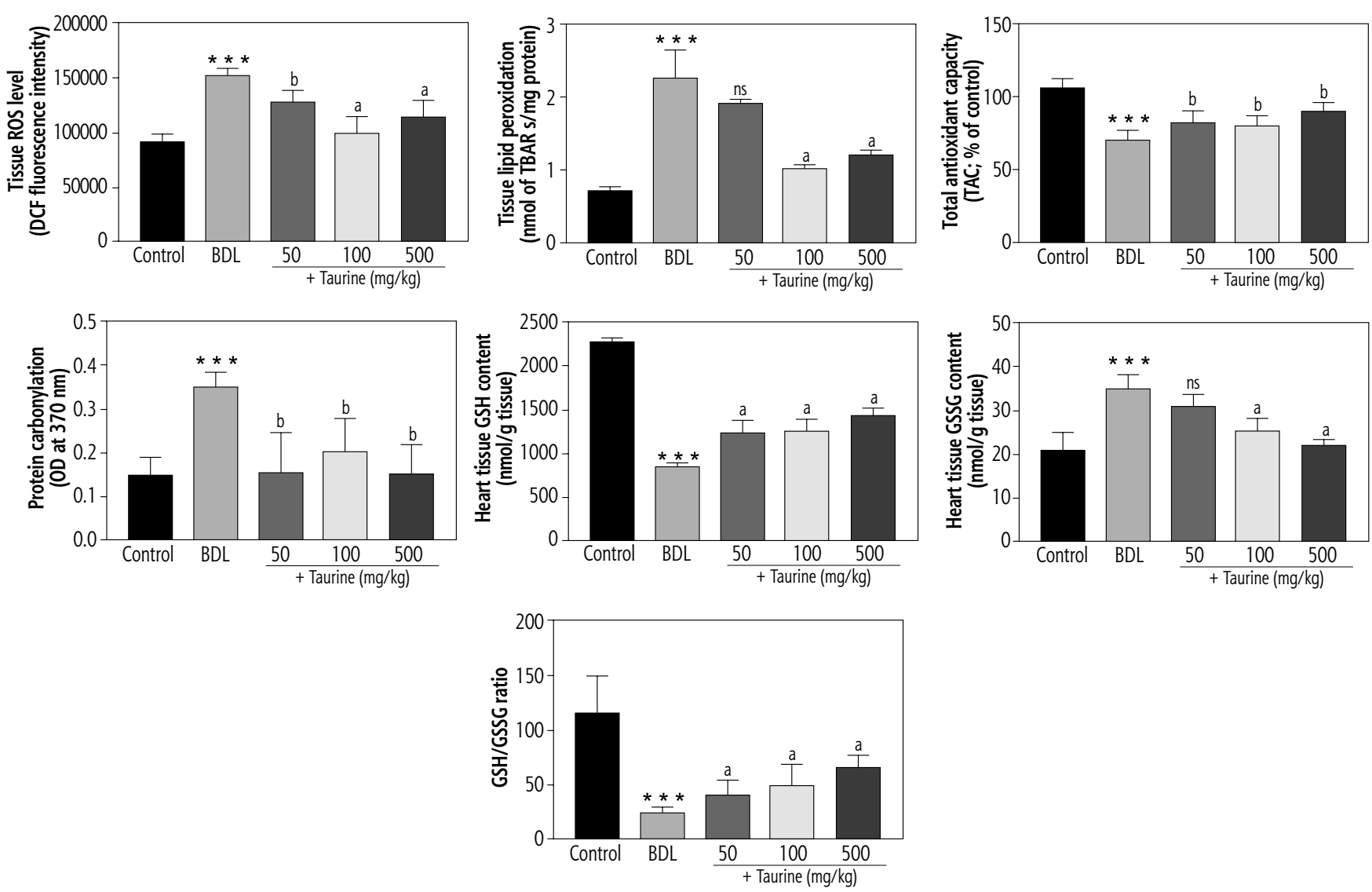

*** Significantly different as compared with the control group $(p<0.001)$

$a, b$ Significantly different as compared with the BDL group ( $p<0.001$ and $p<0.05$ respectively)

ns - not significant as compared with the BDL group

Fig. 2. Biomarkers of oxidative stress in the heart tissue of bile duct ligated (BDL) rats. Data are given as mean $\pm S D(n=8)$

tation $(50,100$, and $500 \mathrm{mg} / \mathrm{kg}$ ) significantly decreased serum biomarkers of organ injury in BDL animals. The effect of Tau on serum markers of organ injury was not dose-dependent in the current study. Moreover, Tau treatment did not significantly change serum levels of $\gamma$-GT, ALP, bile acids, or bilirubin (Fig. 1).

It was found that biomarkers of oxidative stress were significantly increased in the heart tissue of BDL animals (Fig. 2). A significant increase in ROS level, lipid peroxidation, and protein carbonylation, as well as decreased total antioxidant capacity, were detected in the heart tissue of the BDL rats. Significant glutathione depletion, in addition to increased oxidized glutathione (GSSG) level, was also evident in the BDL group. It was found that Tau treatment $(50,100$, and $500 \mathrm{mg} / \mathrm{kg})$ significantly ameliorated biomarkers of oxidative stress in the heart tissue of BDL animals (Fig. 2).

Significant deterioration of mitochondrial indices of functionality was detected in the heart mitochondria isolated from BDL animals (Fig. 3). Mitochondrial depolarization, decreased dehydrogenase activity, mitochondrial permeabilization, lipid peroxidation, and depleted ATP contents were evident in the BDL group. Mitochondria redox balance was also disturbed in BDL animals as the mitochondrial GSH/GSSG ratio was significantly lower. It was found that Tau treatment $(50,100$, and $500 \mathrm{mg} / \mathrm{kg})$ positively improved different indices of the heart mitochondria of BDL rats (Fig. 3).

Significant tissue necrosis, inflammatory cell infiltration, and bile duct proliferation, in addition to hepatic fibrotic changes, confirmed the occurrence of cirrhosis in BDL rats (Fig. 4; 42 days after BDL surgery). On the other hand, heart tissue inflammation was the most prominent histopathological alteration in BDL animals. It was found that Tau supplementation $(50,100$, and $500 \mathrm{mg} / \mathrm{kg})$ significantly decreased heart tissue inflammation in BDL rats (Fig. 4).

\section{Discussion}

It has been well documented that cirrhotic patients suffer from heart injury, arrhythmia, and cardiomyopathy $[3,85]$. On the other hand, the precise mechanisms involved in the pathogenesis of this com- 

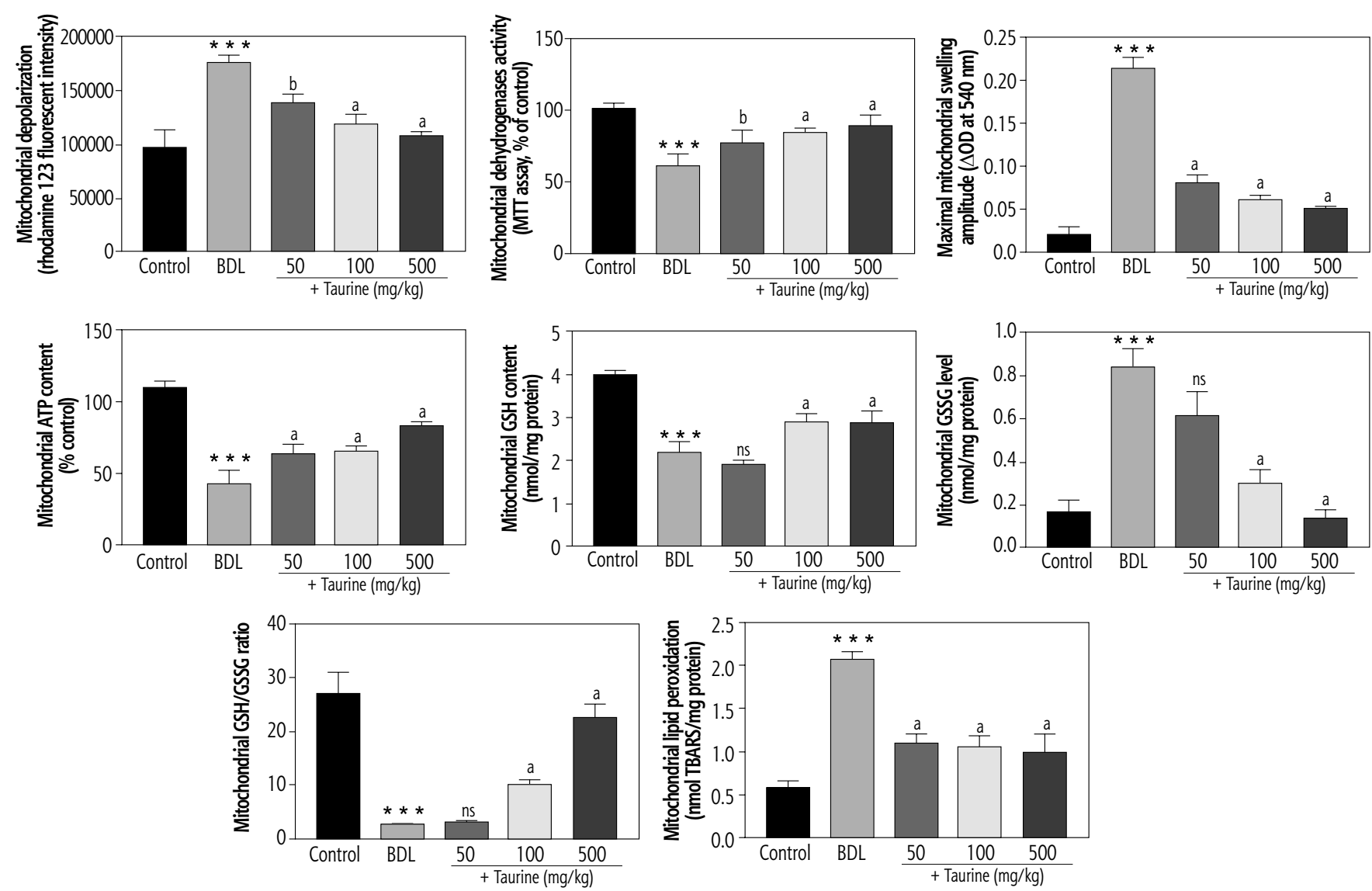

** * Significantly different as compared with the control group $(p<0.001)$

$a, b$ Significantly different as compared with the BDL group ( $p<0.001$ and $p<0.05$ respectively) ns - not significant as compared with the BDL group

Fig. 3. Mitochondrial indices of functionality in the heart tissue of bile duct ligated (BDL) rats. Data are given as mean $\pm S D(n=8)$

plication remain mostly unknown. There is also no appropriate pharmacological and/or ancillary treatment against cirrhosis-associated cardiac dysfunction [3, 4]. In the current study, it was found that heart tissue biomarkers of oxidative stress were significantly elevated in the BDL model of cirrhosis. Moreover, myocardial mitochondrial function was impaired in cirrhotic animals. It was found that Tau treatment $(50,100$, and 500 $\mathrm{mg} / \mathrm{kg}$ ) improved mitochondrial indices of functionality and mitigated oxidative stress in the heart tissue of cirrhotic rats.

The abnormality of heart tissue structure and function has been found in cirrhosis $[1,2,4,86]$. These effects are known as "cirrhotic cardiomyopathy" $[1,87,88]$. A severe decrease in heart muscle contractility, a decrease in cardiac output, and arrhythmia, as well as portal hypertension, are all linked to heart tissue injury in cirrhotic patients [1, 2, 4, 86, 87]. Cirrhotic cardiomyopathy and heart injury could lead to a series of severe and complicated events which threaten the patient's life $[4,86]$.
The histopathological alterations of cardiac tissue in cirrhosis include myocardial hypertrophy, cardiomyocyte edema, exudation, tissue fibrosis, nuclear vacuolation, and unusual pigmentation [88]. Usually, cardiac dysfunction is masked in cirrhotic patients because of "auto-treating" hemodynamic changes (e.g., peripheral vasodilation in cirrhosis) [88]. On the other hand, it has been found that myocardial abnormalities become unmasked after major clinical interventions (e.g., liver transplantation) [88-90]. A high rate of patients' death has been reported because of congestive heart failure after liver transplantation and other clinical interventions in cirrhosis [88-90]. Therefore, finding the cellular and molecular events leading to cardiac dysfunction in cirrhosis and investigating the protective properties of clinically applicable ancillary treatments could have great value.

Taurine is the most abundant free amino acid in the human body. Tau is considered a conditionally essential amino acid. Several pharmacological effects have been attributed to Tau $[91,92]$. On the other hand, many investigations mentioned the potential benefi- 

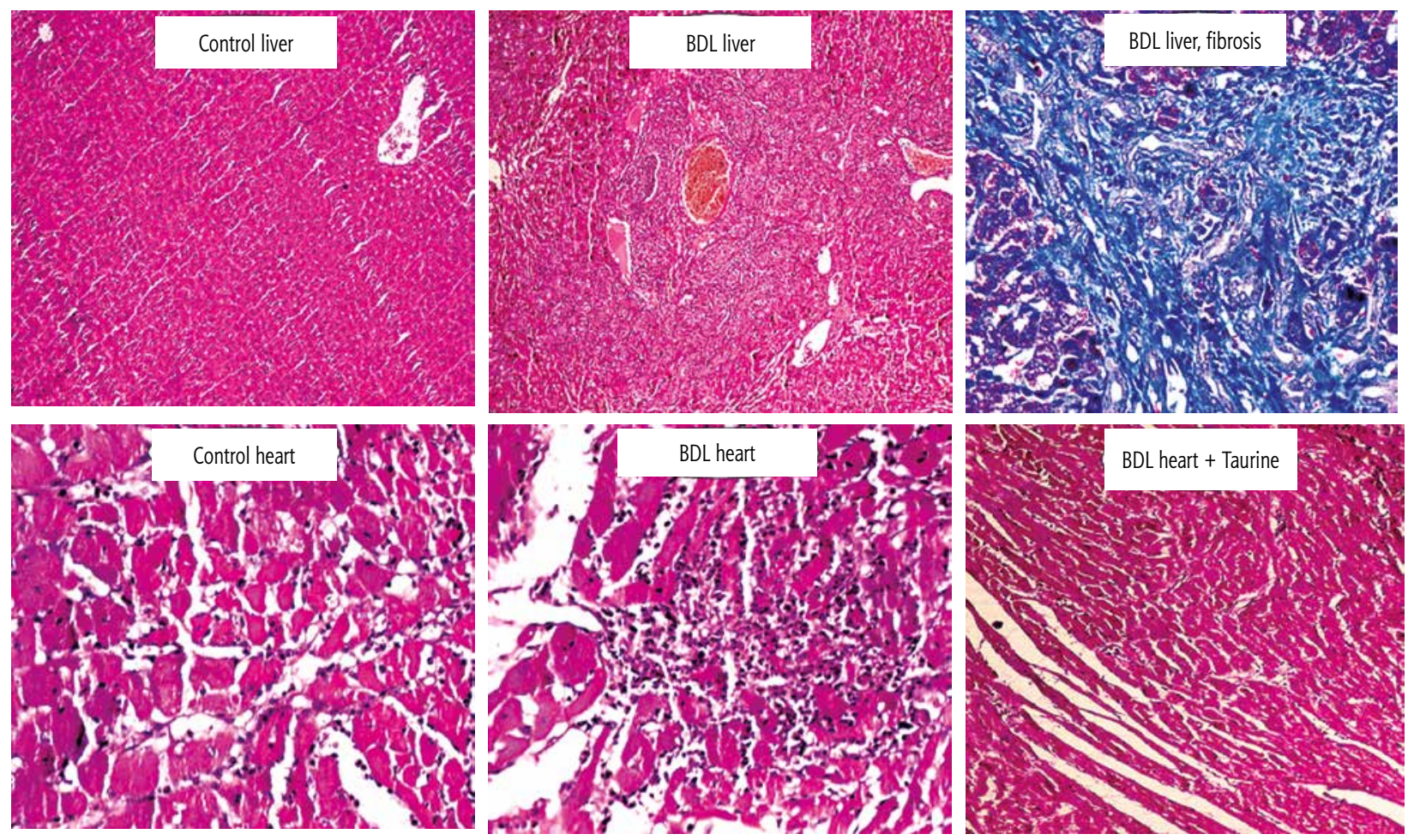

Fig. 4. Rat liver and heart tissue histopathology in control and bile duct ligated (BDL) rats. Significant tissue necrosis, bile duct proliferation, and inflammatory cell infiltration were evident in the liver of BDL animals. Liver histopathological alterations confirmed the occurrence of cirrhosis in the BDL model. Significant tissue inflammation was the most noticeable heart tissue histopathological change in BDL animals. Taurine treatment (50, 100, and $500 \mathrm{mg} / \mathrm{kg}$ ) decreased heart tissue inflammation in BDL rats

cial effects of Tau in cardiovascular diseases $[20,21]$. It has been found that Tau could exhibit regulatory effects on blood pressure [16, 93-96]. Several clinical trials support the view that Tau administration reduces blood pressure in hypertensive patients $[16,93,94]$. Interestingly, this amino acid has been approved for the treatment of congestive heart failure [16]. Physiologically, Tau is found in the heart tissue at very high concentrations $(\approx 25-30 \mathrm{mM})$ [97]. Taurine transporters (TauT) have been identified in cardiomyocytes [98]. These transporters take up Tau from the systemic circulation and increase myocardial Tau content [98]. On the other hand, it has been found that cardiac function is severely compromised in Tau transporter knockout animals $[99,100]$. These data could indicate a role for Tau in cardiac function.

Several mechanisms have been identified for the cytoprotective effects of Tau. It has been well documented that cytoplasmic calcium $\left(\mathrm{Ca}^{2+}\right)$ level and oxidative stress are modulated by Tau supplementation [101-106]. On the other hand, the effect of Tau on mitochondria is one of the most exciting mechanisms by which this amino acid affects cellular function [16, $27,38,103,107-110]$. The regulation of oxidative stress and its associated events is one of the most interesting cytoprotective mechanisms provided by Tau.
Severalstudieshavementioned that Taucan ameliorate oxidative stress in different pathological conditions [20, $42,100,111-113]$. Although the mechanisms underlying the antioxidative effects of Tau need more investigations to be precisely clarified, some investigations mentioned the regulatory effects of this amino acid on mitochondrial function as a pivotal mechanism for its antioxidative properties [43, 114-116]. Interestingly, it has been shown that Tau effectively mitigated mitochondria-facilitated ROS formation and enhanced mitochondrial ATP content $[12,36,37,117-119]$. The protective properties of this amino acid might be mediated through its effect on mitochondria protein synthesis (e.g., mitochondria respiratory chain components) $[120,121]$. Tau contributes to the structure of mitochondrial tRNA $[43,122]$. It has been found that Tau deficiency impairs proper mitochondrial tRNA function and, finally, protein synthesis $[43,122]$. Interestingly, it has also been mentioned that mitochondrial respiratory function and energy metabolism are impaired in the cardiomyocytes of TauT knockout rats [99]. These data could indicate the profound role of Tau in cardiomyocytes. Taurine deficiency in other organs (e.g., in the liver) or deterioration in its transporters (TauT) could also impair fundamental physiological processes such as ammonia detoxification in the liver [123]. 


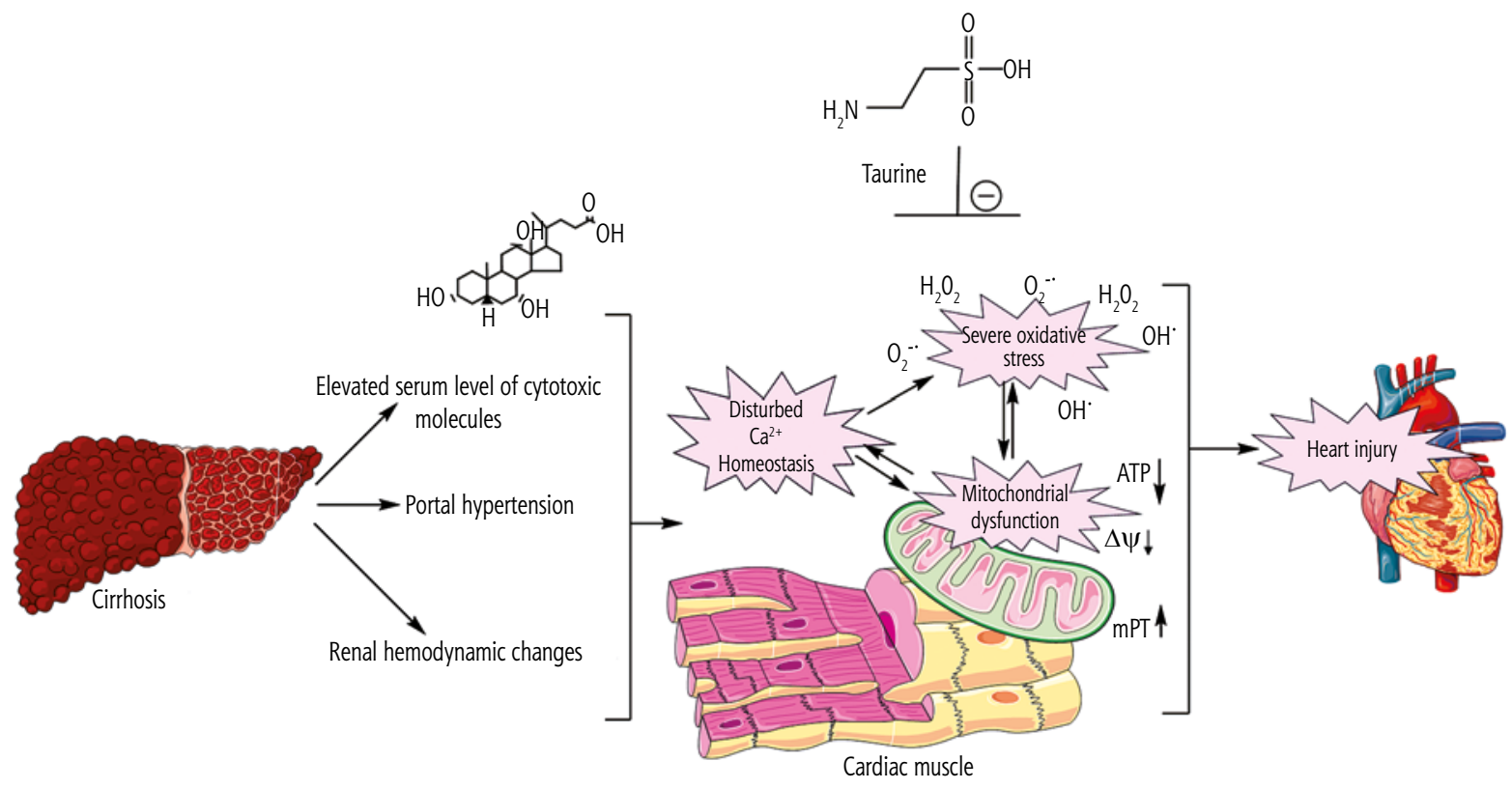

Fig. 5. Cirrhosis-associated complications could proceed to a battery of molecular events in the heart muscle, which finally lead to cardiac dysfunction. Oxidative stress and mitochondrial impairment seem to play a fundamental role in cirrhosis-induced heart injury. Taurine supplementation could regulate mitochondrial function and oxidative stress in the heart tissue of cirrhotic animals.

In the current study, we found that cellular mitochondrial function and energy metabolism were interrupted in the heart tissue of cirrhotic animals. On the other hand, Tau treatment significantly improved mitochondrial function and ATP levels. These data indicate cardiomyocyte mitochondria as a critical therapeutic target for managing cirrhosis-induced heart injury.

Alteration in cardiomyocytes' lipid bilayer has been documented in cirrhosis experimental animal models as well as human cases $[88,124]$. It has been found that the fluidity of the heart tissue plasma membranes is decreased during cirrhosis $[88,124]$. Lipid peroxidation and disturbances in the heart tissue membranes might be connected to deleterious events such as electrocardiographic abnormalities in cirrhosis [125]. Stabilizing biomembranes' lipid bilayer, as well as significant mitigation of lipid peroxidation, are exciting features of Tau [126, 127]. In the current study, we found a high level of TBARs in the heart tissue of cirrhotic animals (Fig. 2). On the other hand, Tau supplementation significantly decreased heart tissue lipid peroxidation in BDL rats (Fig. 2). Therefore, Tau might provide a stable lipid microenvironment in cardiomyocytes of cirrhotic animals.

The effect of Tau on blood pressure has been repeatedly mentioned [128, 129]. Interestingly, it has been found that Tau treatment could effectively decrease portal hypertension in experimental animal models and cirrhotic patients $[130,131]$. These data indicate that Tau administration might ameliorate major circulatory disturbances in cirrhosis. On the other hand, the protective effects of Tau on other cirrhosis-associated complications such as hepatic encephalopathy and liver fibrosis have also been documented [132, 133]. Therefore, this amino acid could find application against cirrhosis-associated complications in clinical settings.

Tissue inflammation was the most prominent histopathological alteration in the current BDL animal model of cirrhosis. It has been well established that Tau possesses anti-inflammatory effects in different experimental models [6, 110, 134-136]. Inflammation is an important source of ROS as a massive amount of reactive species, namely superoxide anion, is produced by neutrophils $[137,138]$. Therefore, the anti-inflammatory effects of Tau might also play an essential role in its antioxidative and cardioprotective properties in cirrhotic animals.

Proper mitochondrial function in cardiomyocytes guarantees a normal level of ATP that is critical for maintaining cardiac contractility and output. Therefore, decreased cardiomyocytes' energy (ATP) level in the heart tissue of cirrhotic animals might contribute to cardiac contractile dysfunction and arrhythmia. Surprisingly, there is scarce investigation on the role of mitochondria in the pathogenesis of cirrhosis-associated myocardial dysfunction. The data obtained from the current BDL animal model of cirrhosis indicate that mitochondrial impairment and cellular energy 
crisis could play a fundamental role in the mechanisms underlying cirrhotic cardiomyopathy and heart failure. Hence, targeting cellular mitochondria could serve as a vital therapeutic point of intervention in cirrhosis-associated cardiac dysfunction (Fig. 5). In the current study, we found that Tau supplementation effectively enhanced cardiac mitochondrial function in cirrhotic animals. Hence, an essential mechanism of cytoprotection provided by Tau might be mediated through preserving mitochondrial function and regulating energy metabolism in cardiomyocytes.

There is no accepted specific treatment for the management of cirrhotic cardiomyopathy. On the other hand, cardiomyocyte mitochondria might serve as potential therapeutic points of intervention in this severe complication. Hence, the administration of antioxidants and mitochondria protecting agents could help in the development of therapeutic strategies against cirrhosis-associated cardiac dysfunction. Tau is an extremely safe amino acid [139]. It has been found that Tau could be administered at very high doses in humans (up to $6 \mathrm{~g} /$ day) [20]. Therefore, this amino acid could be clinically applicable as a therapeutic agent in cirrhotic patients.

\section{Conclusions}

The data obtained from the current study support the potential cardioprotective properties of Tau in cirrhotic animals. The regulation of cardiomyocytes' mitochondrial function and mitigation of oxidative stress biomarkers in the cardiac tissue seem to play a significant role in the protective properties of this amino acid. Evaluating the effect of Tau on critical targets such as the renin-angiotensin system and hemodynamic changes could enhance our understanding of the cardioprotective effects of this amino acid in cirrhosis. On the other hand, further studies are warranted to reveal the clinical significance of these data.

\section{Acknowledgments}

The authors also gratefully acknowledge the Pharmaceutical Sciences Research Center of Shiraz University of Medical Sciences for providing technical facilities to carry out this investigation.

\section{Disclosure}

The authors declare no conflict of interest.

\section{References}

1. Milani A, Zaccaria R, Bombardieri G, et al. Cirrhotic cardiomyopathy. Dig Liver Dis 2007; 39: 507-515.

2. Zardi EM, Abbate A, Zardi DM, et al. Cirrhotic cardiomyopathy. J Am Coll Cardiol 2010; 56: 539-549.

3. Wiese S, Hove JD, Bendtsen F, Møller S. Cirrhotic cardiomyopathy: pathogenesis and clinical relevance. Nat Rev Gastroenterol Hepatol 2014; 11: 177-186.

4. Møller S, Hove JD, Dixen U, Bendtsen F. New insights into cirrhotic cardiomyopathy. Int J Cardiol 2013; 167: 1101-1108.

5. Gaskari SA, Honar H, Lee SS. Therapy insight: Cirrhotic cardiomyopathy. Gastroenterol Hepatol (N Y) 2006; 3: 329-337.

6. Marcinkiewicz J, Kontny E. Taurine and inflammatory diseases. Amino Acids 2014; 46: 7-20.

7. Kumari N, Prentice H, Wu JY. Taurine and its neuroprotective role. Taurine 8. Springer, 2013; 19-27.

8. Schaffer S, Azuma J, Takahashi K, Mozaffari M. Why is taurine cytoprotective? Taurine 5. Springer, 2003; 307-312.

9. Balkan J, Parldar FH, Dogru-Abbasoglu S, et al. The effect of taurine or betaine pretreatment on hepatotoxicity and prooxidant status induced by lipopolysaccharide treatment in the liver of rats. Eur J Gastroenterol Hepatol 2005; 17: 917.

10. Eftekhari A, Ahmadian E, Azarmi Y, et al. The effects of cimetidine, $\mathrm{N}$-acetylcysteine, and taurine on thioridazine metabolic activation and induction of oxidative stress in isolated rat hepatocytes. Pharm Chem J 2018; 51: 965-969.

11. Sarı̈zkan S, Bucak MN, Tuncer PB, et al. The influence of cysteine and taurine on microscopic-oxidative stress parameters and fertilizing ability of bull semen following cryopreservation. Cryobiology 2009; 58: 134-138.

12. Heidari R, Mandegani L, Ghanbarinejad V, et al. Mitochondrial dysfunction as a mechanism involved in the pathogenesis of cirrhosis-associated cholemic nephropathy. Biomed Pharmacother 2019; 109: 271-280.

13. Yalçınkaya $S$, Ünlüçerçi $Y$, Giriş $M$, et al. Oxidative and nitrosative stress and apoptosis in the liver of rats fed on high methionine diet: protective effect of taurine. Nutrition 2009; 25: 436-444.

14. Koyama I, Nakamura T, Ogasawara M, et al. The protective effect of taurine on the biomembrane against damage produced by the oxygen radical. Taurine. Springer, 1992; 355-359.

15. Waterfield CJ, Mesquita M, Parnham P, Timbrell JA. Taurine protects against the cytotoxicity of hydrazine, 1,4-naphthoquinone and carbon tetrachloride in isolated rat hepatocytes. Biochem Pharmacol 1993; 46: 589-595.

16. Schaffer S, Kim HW. Effects and mechanisms of taurine as a therapeutic agent. Biomol Ther (Seoul) 2018; 26: 225-241.

17. Menzie J, Pan C, Prentice H, Wu JY. Taurine and central nervous system disorders. Amino Acids 2012; 46: 31-46.

18. Miyazaki T, Matsuzaki Y. Taurine and liver diseases: a focus on the heterogeneous protective properties of taurine. Amino Acids 2012; 46: 101-110.

19. De Luca A, Pierno S, Camerino DC. Taurine: the appeal of a safe amino acid for skeletal muscle disorders. J Transl Med 2015; 13: 243.

20. Zhang F, Tong L, Qiao H, et al. Taurine attenuates multiple organ injury induced by intestinal ischemia reperfusion in rats. J Surg Res 2008; 149: 101-109.

21. Zulli A. Taurine in cardiovascular disease. Curr Opin Clin Nutr Metab Care 2011; 14: 57-60.

22. Yamori Y, Taguchi T, Hamada A, et al. Taurine in health and diseases: consistent evidence from experimental and epidemiological studies. J Biomed Sci 2010; 17: S6.

23. Wójcik OP, Koenig KL, Zeleniuch-Jacquotte A, et al. The potential protective effects of taurine on coronary heart disease. Atherosclerosis 2010; 208: 19-25. 
24. Das J, Ghosh J, Manna P, Sil PC. Taurine suppresses doxorubicin-triggered oxidative stress and cardiac apoptosis in rat via up-regulation of PI3-K/Akt and inhibition of p53, p38-JNK. Biochem Pharmacol 2011; 81: 891-909.

25. Shimada K, Jong CJ, Takahashi K, Schaffer SW. Role of ROS production and turnover in the antioxidant activity of taurine. Taurine 9. Springer, 2015; 581-596.

26. Ommati MM, Heidari R, Ghanbarinejad V, et al. Taurine treatment provides neuroprotection in a mouse model of manganism. Biol Trace Elem Res 2019; 190: 384-395.

27. Das J, Ghosh J, Manna P, et al. Taurine protects rat testes against $\mathrm{NaAsO} 2$-induced oxidative stress and apoptosis via mitochondrial dependent and independent pathways. Toxicol Lett 2009; 187: 201-210.

28. Saransaari P, Oja SS. Taurine and neural cell damage. Amino Acids 2000; 19: 509-526.

29. Tsunekawa M, Wang S, Kato T, et al. Taurine administration mitigates cisplatin induced acute nephrotoxicity by decreasing DNA damage and inflammation: an immunocytochemical study. Taurine 10. Springer, Dordrecht 2017; 703-716.

30. Heidari R, Babaei H, Eghbal MA. Amodiaquine-induced toxicity in isolated rat hepatocytes and the cytoprotective effects of taurine and/or N-acetyl cysteine. Res Pharm Sci 2014; 9: 97-105.

31. Das J, Ghosh J, Manna P, Sil PC. Acetaminophen induced acute liver failure via oxidative stress and JNK activation: Protective role of taurine by the suppression of cytochrome P450 2E1. Free Radical Res 2010; 44: 340-355.

32. Parvez S, Tabassum H, Banerjee BD, Raisuddin S. Taurine prevents tamoxifen-induced mitochondrial oxidative damage in mice. Basic Clin Pharmacol Toxicol 2008; 102: 382-387.

33. Idrissi AE. Taurine increases mitochondrial buffering of calcium: role in neuroprotection. Amino Acids 2006; 34: 321-328.

34. Hansen SH, Andersen ML, Cornett C, et al. A role for taurine in mitochondrial function. J Biomed Sci 2010; 17: 1-8.

35. Lambert IH, Kristensen DM, Holm JB, Mortensen OH. Physiological role of taurine - from organism to organelle. Acta Physiologica 2015; 213: 191-212.

36. Heidari R, Babaei H, Eghbal MA. Cytoprotective effects of taurine against toxicity induced by isoniazid and hydrazine in isolated rat hepatocytes. Arch Indust Hyg Toxicol 2013; 64: 201-210.

37. Niknahad H, Jamshidzadeh A, Heidari R, et al. Ammonia-induced mitochondrial dysfunction and energy metabolism disturbances in isolated brain and liver mitochondria, and the effect of taurine administration: relevance to hepatic encephalopathy treatment. Clin Exp Hepatol 2017; 3: 141-151.

38. Hansen SH, Andersen ML, Birkedal H, et al. The important role of taurine in oxidative metabolism. Adv Exp Med Biol 2006; 583: 129-135.

39. Idrissi AE, Trenkner E. Growth factors and taurine protect against excitotoxicity by stabilizing calcium homeostasis and energy metabolism. J Neurosci 1999; 19: 9459-9468.

40. Das J, Ghosh J, Manna P, Sil PC. Protective role of taurine against arsenic-induced mitochondria-dependent hepatic apoptosis via the inhibition of PKC $\delta$-JNK pathway. PLoS One 2010; 5: e12602.

41. Aly HAA, Khafagy RM. Taurine reverses endosulfan-induced oxidative stress and apoptosis in adult rat testis. Food Chem Toxicol 2014; 64: 1-9.

42. Zhang Z, Liu D, Yi B, et al. Taurine supplementation reduces oxidative stress and protects the liver in an iron-overload murine model. Mol Med Report 2014; 10: 2255-2262.

43. Schaffer SW, Azuma J, Mozaffari M. Role of antioxidant activity of taurine in diabetes. Can J Physiol Pharmacol 2009; 87: 91-99.
44. Leon $\mathrm{R}, \mathrm{Wu} \mathrm{H}$, Jin $\mathrm{Y}$, et al. Protective function of taurine in glutamate-induced apoptosis in cultured neurons. J Neurosci Res 2009; 87: 1185-1194.

45. Sun M, Gu Y, Zhao Y, Xu C. Protective functions of taurine against experimental stroke through depressing mitochondria-mediated cell death in rats. Amino Acids 2011; 40: 1419-1429.

46. Tag CG, Weiskirchen S, Hittatiya K, et al. Induction of experimental obstructive cholestasis in mice. Lab Anim 2015; 49: 70-80.

47. Heidari R, Niknahad H. The role and study of mitochondrial impairment and oxidative stress in cholestasis. In: Vinken $M$ (ed.). Experimental Cholestasis Research: Humana Press, 2019.

48. Jamshidzadeh A, Niknahad H, Heidari R, et al. Carnosine protects brain mitochondria under hyperammonemic conditions: Relevance to hepatic encephalopathy treatment. PharmaNutrition 2017; 5: 58-63.

49. Ommati MM, Heidari R, Manthari RK, et al. Paternal exposure to arsenic resulted in oxidative stress, autophagy, and mitochondrial impairments in the HPG axis of pubertal male offspring. Chemosphere 2019; 236: 124325.

50. Ahmadian E, Khosroushahi AY, Eftekhari A, et al. Novel angiotensin receptor blocker, azilsartan induces oxidative stress and NFkB-mediated apoptosis in hepatocellular carcinoma cell line HepG2. Biomed Pharmacother 2018; 99: 939-946.

51. Socci DJ, Bjugstad KB, Jones HC, et al. Evidence that oxidative stress is associated with the pathophysiology of inherited hydrocephalus in the H-Tx rat model. Exp Neurol 1999; 155: 109-117.

52. Jamshidzadeh A, Heidari R, Mohammadi-Samani S, et al. A comparison between the nephrotoxic profile of gentamicin and gentamicin nanoparticles in mice. J Biochem Mol Toxicol 2015; 29: $57-62$.

53. Heidari R, Esmailie N, Azarpira N, et al. Effect of Thiol-reducing agents and antioxidants on sulfasalazine-induced hepatic injury in normotermic recirculating isolated perfused rat liver. Toxicological Res 2016; 32: 133-140.

54. Eftekhari A, Ahmadian E, Panahi-Azar V, et al. Hepatoprotective and free radical scavenging actions of quercetin nanoparticles on aflatoxin B1-induced liver damage: in vitro/in vivo studies. Artif Cell Nanomed Biotechnol 2018; 46: 411-420.

55. Ommati MM, Farshad O, Ghanbarinejad V, et al. The nephroprotective role of carnosine against ifosfamide-induced renal injury and electrolytes imbalance is mediated via the regulation of mitochondrial function and alleviation of oxidative stress. Drug Res (Stuttg) 2020; 70: 49-56.

56. Heidari R, Babaei H, Roshangar L, Eghbal MA. Effects of enzyme induction and/or glutathione depletion on methimazole-induced hepatotoxicity in mice and the protective role of $\mathrm{N}$-acetylcysteine. Adv Pharm Bull 2014; 4: 21-28.

57. Gülçin İ. $\mathrm{Fe}(3+)-\mathrm{Fe}(2+)$ transformation method: an important antioxidant assay. Methods Mol Biol 2015; 1208: 233-246.

58. Ommati MM, Farshad O, Mousavi K, et al. Betaine supplementation mitigates intestinal damage and decreases serum bacterial endotoxin in cirrhotic rats. PharmaNutrition 2020; 12: 100179.

59. Alía M, Horcajo C, Bravo L, Goya L. Effect of grape antioxidant dietary fiber on the total antioxidant capacity and the activity of liver antioxidant enzymes in rats. Nutr Res 2003; 23: 1251-1267.

60. Weber D, Davies MJ, Grune T. Determination of protein carbonyls in plasma, cell extracts, tissue homogenates, isolated proteins: Focus on sample preparation and derivatization conditions. Redox Biol 2015; 5: 367-380.

61. Ommati MM, Farshad O, Niknahad H, et al. Cholestasis-associated reproductive toxicity in male and female rats: The fundamental role of mitochondrial impairment and oxidative stress. Toxicol Lett 2019; 316: 60-72. 
62. Caro AA, Adlong LW, Crocker SJ, et al. Effect of garlic-derived organosulfur compounds on mitochondrial function and integrity in isolated mouse liver mitochondria. Toxicol Lett 2012; 214: 166-174.

63. Fernández-Vizarra E, Ferrín G, Pérez-Martos A, et al. Isolation of mitochondria for biogenetical studies: An update. Mitochondrion 2010; 10: 253-262.

64. Niknahad H, Heidari R, Mohammadzadeh R, et al. Sulfasalazine induces mitochondrial dysfunction and renal injury. Ren Fail 2017; 39: 745-753.

65. Bradford MM. A rapid and sensitive method for the quantitation of microgram quantities of protein utilizing the principle of protein-dye binding. Anal Biochem 1976; 72: 248-254.

66. Niknahad H, Heidari R, Alzuhairi AM, Najibi A. Mitochondrial dysfunction as a mechanism for pioglitazone-induced injury toward HepG2. Cell Pharm Sci 2015; 20: 169-174.

67. Ommati MM, Heidari R, Jamshidzadeh A, et al. Dual effects of sulfasalazine on rat sperm characteristics, spermatogenesis, and steroidogenesis in two experimental models. Toxicol Lett 2018; 284: 46-55.

68. Ommati MM, Jamshidzadeh A, Heidari R, et al. Carnosine and histidine supplementation blunt lead-induced reproductive toxicity through antioxidative and mitochondria-dependent mechanisms. Biol Trace Elem Res 2019; 187: 151-162.

69. Ommati MM, Farshad O, Mousavi K, et al. Chlorogenic acid supplementation improves skeletal muscle mitochondrial function in a rat model of resistance training. Biologia 2020; doi: 10.2478/s11756-020-00429-7.

70. Heidari R, Babaei H, Eghbal M. Mechanisms of methimazole cytotoxicity in isolated rat hepatocytes. Drug Chem Toxicol 2013; 36: 403-411.

71. Heidari R, Babaei H, Eghbal MA. Ameliorative effects of taurine against methimazole-induced cytotoxicity in isolated rat hepatocytes. Sci Pharm 2012; 80: 987-999.

72. Abdoli N, Heidari R, Azarmi Y, Eghbal MA. Mechanisms of the statins cytotoxicity in freshly isolated rat hepatocytes. J Biochem Mol Toxicol 2013; 27: 287-294.

73. Ahmadian E, Babaei H, Mohajjel Nayebi A, et al. Venlafaxine-induced cytotoxicity towards isolated rat hepatocytes involves oxidative stress and mitochondrial/lysosomal dysfunction. Adv Pharm Bull 2016; 6: 521-530.

74. Ommati MM, Manthari RK, Tikka C, et al. Arsenic-induced autophagic alterations and mitochondrial impairments in HPG-S axis of mature male mice offspring (F1-generation): A persistent toxicity study. Toxicol Lett 2020; 326: 83-98.

75. Heidari R, Babaei H, Eghbal MA. Cytoprotective effects of organosulfur compounds against methimazole induced toxicity in isolated rat hepatocytes. Adv Pharm Bull 2013; 3: 135-142.

76. Niknahad H, Jamshidzadeh A, Heidari R, et al. The postulated hepatotoxic metabolite of methimazole causes mitochondrial dysfunction and energy metabolism disturbances in liver. Pharm Sci 2016; 22: 217-226.

77. Heidari R, Arabnezhad MR, Ommati MM, et al. Boldine supplementation regulates mitochondrial function and oxidative stress in a rat model of hepatotoxicity. Pharm Sci 2019; 25: 1-10.

78. Jamshidzadeh A, Heidari R, Latifpour Z, et al. Carnosine ameliorates liver fibrosis and hyperammonemia in cirrhotic rats. Clin Res Hepatol Gastroenterol 2017; 41: 424-434.

79. Meeks RG, Harrison S. Hepatotoxicology. CRC Press, New York 1991.

80. Ommati MM, Heidari R, Ghanbarinejad V, et al. Taurine treatment provides neuroprotection in a mouse model of manganism. Biol Trace Elem Res 2019; 190: 384-395.
81. Truong DH, Eghbal MA, Hindmarsh W, et al. Molecular mechanisms of hydrogen sulfide toxicity. Drug Metab Rev 2006; 38: 733-744.

82. Heidari R, Jafari F, Khodaei F, et al. Mechanism of valproic acid-induced Fanconi syndrome involves mitochondrial dysfunction and oxidative stress in rat kidney. Nephrology 2017; 23: 351-361.

83. Emadi E, Abdoli N, Ghanbarinejad V, et al. The potential role of mitochondrial impairment in the pathogenesis of imatinib-induced renal injury. Heliyon 2019; 5: e01996.

84. Caro AA, Cederbaum AI. Synergistic toxicity of iron and arachidonic acid in HepG2 cells overexpressing CYP2E1. Mol Pharmacol 2001; 60: 742-752.

85. Lunseth JH, Olmstead EG, Forks G, Abboud F. A study of heart disease in one hundred eight hospitalized patients dying with portal cirrhosis. Arch Intern Med 1958; 102: 405-413.

86. Mozos I. Arrhythmia risk in liver cirrhosis. World J Hepatol 2015; 7: 662-672.

87. Wong F. Cirrhotic cardiomyopathy. Hepatol Int 2008; 3: 294304.

88. Ma Z, Lee SS. Cirrhotic cardiomyopathy: getting to the heart of the matter. Hepatology 1996; 24: 451-459.

89. Huonker M, Schumacher YO, Ochs A, et al. Cardiac function and haemodynamics in alcoholic cirrhosis and effects of the transjugular intrahepatic portosystemic stent shunt. Gut 1999; 44: 743-748.

90. Møller S, Henriksen JH. Cardiopulmonary complications in chronic liver disease. World J Gastroenterol 2006; 12: 526-538.

91. Huxtable RJ, Michalk D. Taurine in health and disease. Springer Science \& Business Media, 2013.

92. Timbrell JA, Seabra V, Waterfield CJ. The in vivo and in vitro protective properties of taurine. Gen Pharmacol 1995; 26: 453-462.

93. Sun Q, Wang B, Li Y, et al. Taurine supplementation lowers blood pressure and improves vascular function in prehypertension: randomized, double-blind, placebo-controlled study. Hypertension 2016; 67: 541-549.

94. Yamori Y, Taguchi T, Hamada A, et al. Taurine in health and diseases: consistent evidence from experimental and epidemiological studies. J Biomed Sci 2010; 17 Suppl 1: S6.

95. Hu J, Xu X, Yang J, et al. Antihypertensive effect of taurine in rat. Adv Exp Med Biol 2009; 643: 75-84.

96. Katakawa M, Fukuda N, Tsunemi A, et al. Taurine and magnesium supplementation enhances the function of endothelial progenitor cells through antioxidation in healthy men and spontaneously hypertensive rats. Hypertens Res 2016; 39: 848856

97. Pasantes-Morales H, Quesada O, Morán J. Taurine: an osmolyte in mammalian tissues. In: Schaffer S, Lombardini JB, Huxtable RJ (eds.). Taurine 3: Cellular and Regulatory Mechanisms. Springer US, Boston, MA 1998: 209-217.

98. Ito T, Oishi S, Takai M, et al. Cardiac and skeletal muscle abnormality in taurine transporter-knockout mice. J Biomed Sci 2010; 17: S20.

99. Ito T, Kimura Y, Uozumi Y, et al. Taurine depletion caused by knocking out the taurine transporter gene leads to cardiomyopathy with cardiac atrophy. J Mol Cell Cardiol 2008; 44: 927-937.

100. Yang Y, Zhang Y, Liu X, et al. Exogenous taurine attenuates mitochondrial oxidative stress and endoplasmic reticulum stress in rat cardiomyocytes. Acta Biochim Biophys Sin (Shanghai) 2013; 45: 359-367.

101. Oja SS, Saransaari P. Taurine as osmoregulator and neuromodulator in the brain. Metab Brain Dis 1996; 11: 153-164. 
102. Law RO, Zielinska M, Albrecht J. Taurine counteracts cell swelling in rat cerebrocortical slices exposed to ammonia in vitro and in vivo. Taurine 5. Springer, 2003: 123-129.

103. El Idrissi A, Trenkner E. Taurine regulates mitochondrial calcium homeostasis. Taurine 5. Springer, 2003; 527-536.

104. Pasantes-Morales H, Quesada O, Moran J. Taurine: an osmolyte in mammalian tissues. Taurine 3. Springer, 1998; 209-217.

105. Kendler BS. Taurine: an overview of its role in preventive medicine. Prev Med 1989; 18: 79-100.

106. Wright CE, Tallan HH, Lin YY. Taurine: biological update. Annu Rev Biochem 1986; 55: 427-453.

107. Hansen SH, Grunnet N. Taurine, glutathione and bioenergetics. In: Idrissi AE, L'Amoreaux WJ (eds.). Taurine 8. Springer, New York 2013; 3-12.

108. Palmi M, Youmbi GT, Sgaragli G, et al. The mitochondrial permeability transition and taurine. Taurine 4 . Springer, 2002, 87-96.

109. Hansen SH, Andersen ML, Cornett C, et al. A role for taurine in mitochondrial function. J Biomed Sci 2010; 17: S23.

110. Schuller-Levis GB, Park E. Taurine: New implications for an old amino acid. FEMS Microbiol Lett 2003; 226: 195-202.

111. Ghosh M, Pal S, Sil PC. Taurine attenuates nano-copper-induced oxidative hepatic damage via mitochondria-dependent and NF- $\mathrm{KB} / \mathrm{TNF}-\alpha$-mediated pathway. Toxicol Res 2014; 3: 474-486.

112. Pushpakiran G, Mahalakshmi K, Anuradha CV. Taurine restores ethanol-induced depletion of antioxidants and attenuates oxidative stress in rat tissues. Amino Acids 2004; 27: 91-96.

113. Heidari R, Jamshidzadeh A, Niknahad H, et al. The hepatoprotection provided by taurine and glycine against antineoplastic drugs induced liver injury in an ex vivo model of normothermic recirculating isolated perfused rat liver. Trend Pharm Sci 2016; 2: 59-76.

114. Xu S, He M, Zhong M, et al. The neuroprotective effects of taurine against nickel by reducing oxidative stress and maintaining mitochondrial function in cortical neurons. Neurosci Lett 2015; 590: 52-57.

115. Palmi M, Youmbi GT, Fusi F, et al. Potentiation of mitochondrial $\mathrm{Ca} 2+$ sequestration by taurine. Biochem Pharmacol 1999; 58: 1123-1131.

116. Shimada K, Jong CJ, Takahashi K, Schaffer SW. Role of ROS production and turnover in the antioxidant activity of taurine. Adv Exp Med Biol 2015; 803: 581-596.

117. Heidari R, Abdoli N, Ommati MM, et al. Mitochondrial impairment induced by chenodeoxycholic acid: The protective effect of taurine and carnosine supplementation. Trend Pharm Sci 2018; 4

118. Jamshidzadeh A, Heidari R, Abasvali M, et al. Taurine treatment preserves brain and liver mitochondrial function in a rat model of fulminant hepatic failure and hyperammonemia. Biomed Pharmacother 2017; 86: 514-520.

119. Niknahad H, Jamshidzadeh A, Heidari R, et al. Ammonia-induced mitochondrial dysfunction and energy metabolism disturbances in isolated brain and liver mitochondria, and the effect of taurine administration: relevance to hepatic encephalopathy treatment. Clin Exp Hepatol 2017; 3: 141-151.

120. Chang L, Zhao J, Xu J, et al. Effects of taurine and homocysteine on calcium homeostasis and hydrogen peroxide and superoxide anions in rat myocardial mitochondria. Clin Exp Pharmacol Physiol 2004; 31: 237-243.

121. Li CY, Deng YL, Sun BH. Taurine protected kidney from oxidative injury through mitochondrial-linked pathway in a rat model of nephrolithiasis. Urol Res 2009; 37: 211-220.
122. Suzuki T, Suzuki T, Wada T, et al. Taurine as a constituent of mitochondrial tRNAs: new insights into the functions of taurine and human mitochondrial diseases. EMBO J 2002; 21: 6581-6589.

123. Qvartskhava N, Jin CJ, Buschmann T, et al. Taurine transporter (TauT) deficiency impairs ammonia detoxification in mouse liver. Proc Natl Acad Sci U S A 2019; 116: 6313-6318.

124. Ma Z, Meddings JB, Lee SS. Membrane physical properties determine cardiac beta-adrenergic receptor function in cirrhotic rats. Am J Physiol 1994; 267: G87-93.

125. Kempler P, Szalay F, Váradi A, et al. Prolongation of the QTc-interval reflects the severity of autonomic neuropathy in primary biliary cirrhosis and in other non-alcoholic liver diseases. Z Gastroenterol 1993; 31 Suppl 2: 96-98.

126. Tadolini B, Pintus G, Pinna GG, et al. Effects of taurine and hypotaurine on lipid peroxidation. Biochem Biophys Res Commun 1995; 213: 820-826.

127. Parildar-Karpuzoglu H, Mehmetçik G, Ozdemirler-Erata G, et al. Effect of taurine treatment on pro-oxidant-antioxidant balance in livers and brains of old rats. Pharmacol Rep 2008; 60: 673-678.

128. Maia AR, Batista TM, Victorio JA, et al. Taurine supplementation reduces blood pressure and prevents endothelial dysfunction and oxidative stress in post-weaning protein-restricted rats. PLoS One 2014; 9: e105851.

129. El Idrissi A, Okeke E, Yan X, et al. Taurine regulation of blood pressure and vasoactivity. Taurine 8. Springer, 2013; 407-425.

130. Liang J, Deng X, Lin ZX, et al. Attenuation of portal hypertension by natural taurine in rats with liver cirrhosis. World J Gastroenterol 2009; 15: 4529-4537.

131. Schwarzer R, Kivaranovic D, Mandorfer M, et al. Randomised clinical study: the effects of oral taurine $6 \mathrm{~g} /$ day vs placebo on portal hypertension. Aliment Pharmacol Ther 2018; 47: 86-94.

132. Heidari R, Jamshidzadeh A, Niknahad H, et al. Effect of taurine on chronic and acute liver injury: Focus on blood and brain ammonia. Toxicol Rep 2016; 3: 870-879.

133. Heidari R. Brain mitochondria as potential therapeutic targets for managing hepatic encephalopathy. Life Sci 2019; 218: 65-80.

134. Kato T, Okita S, Wang S, et al. The effects of taurine administration against inflammation in heavily exercised skeletal muscle of rats. Adv Exp Med Biol 2015; 803: 773-784.

135. Niu X, Zheng S, Liu H, Li S. Protective effects of taurine against inflammation, apoptosis, and oxidative stress in brain injury. Mol Med Report 2018; 18: 4516-4522.

136. Su Y, Fan W, Ma Z, et al. Taurine improves functional and histological outcomes and reduces inflammation in traumatic brain injury. Neuroscience 2014; 266: 56-65.

137. Khansari N, Shakiba Y, Mahmoudi M. Chronic inflammation and oxidative stress as a major cause of age- related diseases and cancer. Rec Patent Inflamm Allergy Drug Disc 2009; 3: 73-80.

138. Babior BM. Phagocytes and oxidative stress. Am J Med 2000; 109: 33-44.

139. Shao A, Hathcock JN. Risk assessment for the amino acids taurine, l-glutamine and l-arginine. Regul Toxicol Pharmacol 2008; 50: 376-399. 